\title{
Combining Ability for Yield and Yield Components in Groundnut (Arachis hypogaea L.)
}

\author{
Ishu Kumar Khute*, S.S. Rao, Preeti Painkra and Naveen Markam \\ Department of Genetics and Plant Breeding, College of Agriculture, Indira Gandhi Krishi \\ Vishwavidyalaya, Raipur - 492 012, Chhattisgarh, India \\ *Corresponding author
}

\section{A B S T R A C T}

Keywords

Half diallel, General combining ability, Specific combining ability, Groundnut

Article Info

Accepted:

24 January 2018

Available Online:

10 February 2018
The present investigation was conducted to study general and specific combining ability in 21 genotypes including 6 parents. The parent JL-501 identified good general combiner for number of primary branches per plant, pod size, harvest index and shelling percentage indicating this parent can be used for further crop improvement programme and the parent Girnar-3 showed significant positive gca effects for number of secondary branches per plant whereas the parent ICGV 91114 also identified as a best combiner for seed weight per plant. The crosses Kadiri-3 x JL-501 proves to the best combination for pod yield and early maturity and Kadiri- 6 x Kadiri-3 for number of kernel per plant, harvest index and most of the traits that can be used for further breeding programmes.

\section{Introduction}

Groundnut (Arachis hypogaea L.), chromosome no. $2 \mathrm{n}=40$ is an important monoecious annual legume in the world mainly grown for edible oil, food and animal feed (Pande et al., 2003; Upadhyaya et al., 2006). The flowers are a typical pea flower in shape, 2 to $4 \mathrm{~cm}$ (0.8 to1.6") across, yellow with reddish veining. The specific name, hypogaea means "under the earth"; after pollination, the flower stalk elongates, causing it to bend until the ovary touches the ground. Continued stalk growth then pushes the ovary underground where the mature fruit develops into a legume pod, the peanut - a classical example of geocarpy. Pods are 3 to $7 \mathrm{~cm}$ $\left(1.2^{11}\right.$ to $\left.2.8^{11}\right)$ long, normally containing 1 to 4 seeds. Because, in botanical terms, "nut" specifically refers to indehiscent fruit, the peanut is not technically a nut, but rather a legume. Peanuts are often served in a similar manner to true nuts in many western cuisines, and are often referred to as a nut in common English (Young, 2006).

It is the third most important food crop and the fourth most important oilseed crop of the world. Groundnut seeds contain $40-50 \%$ fat, $20-50 \%$ protein and $10-20 \%$ carbohydrate. 
Groundnut seeds are a nutritional source of vitamin E, niacin, calcium, phosphorus, magnesium, zinc, iron, riboflavin, thiamin and potassium. Cultivated groundnut was originated from South America (Wiess, 2000). It is one of the most popular and universal crops cultivated in more than 100 countries in six continents (Nwokoto, 1996).

All parts of the peanut plant can be easily utilized. Besides income for farmers, groundnut provides an inexpensive source of high quality dietary protein and edible oil. The vast food preparations incorporating groundnut to improve the protein level has helped in no small way in reducing malnutrition in the developing countries. The special taste and flavour of foods containing groundnut is very important in the acceptance of these food preparations. It is estimated that the shell represents about $25 \%$ of the dry weight of unshelled peanut, and the kernel comprises $75 \%$. Groundnut seeds contain high quality edible oil (50\%), easily digestible protein $(25 \%)$, carbohydrates $(20 \%)$, vitamin E, niacin, folacin, calcium, phosphorus, magnesium, zinc, iron, riboflavin, thiamine and potassium (Anonymous, 2004). Worthington and Hammons (1971) reported that the seed has several uses as whole seed or processed to make peanut butter, oil, soups, stews and other products. Nearly two thirds of all groundnuts are crushed for oil (Bunting et al., 1985).

Combining ability analysis helps in the identification of parents with high general combining ability (GCA) effects and cross combinations with high specific combining ability (SCA) effects. Additive and nonadditive gene action in the parents estimated through combining ability analysis may be useful in determining the possibility for commercial exploitation of heterosis. The average performance of a parent or inbred in a series of cross combinations is known as its 'general combining ability' and the performance of two specific inbred in a particular cross combination is known as its 'specific combining ability'.

\section{Materials and Methods}

In crossing block six varieties Jyoti, Girnar-3, Kadiri-6, Kadiri-3, ICGV 91114 and JL-501 were sown during Kharif 2015 at Research Farm, Department of Genetics and Plant Breeding, Indira Gandhi Krishi Vishwavidyalaya, Raipur (C.G.). Selected six parents were crossed to generate a set of hybrids in a half diallel manner as proposed by Kempthorne (1957). Three lines of each variety are sown in spacing of $45 \mathrm{~cm}$ row to row and $25 \mathrm{~cm}$ plant to plant.

At the onset of flowering, for 1-2 days, all the flowers on the female parents should be removed to help stimulate profuse flowering. Removal of anthers from buds flowers before their dehiscence to avoid self-pollination. The leaf is pulled down gently to expose these buds.

The bud is held gently between the thumb and index finger of the left hand. Using forceps held in the right hand, the single sepal opposite the standard petal is pulled down. The fused sepal is also folded down and held back. The standard is then gently and carefully opened with forceps and is held back by the thumb and index finger. The wing petals are pulled down locking them with the standard. The keel is pulled outwards by its ridge with forceps to expose the anthers. All the anthers are removed with the filaments from their bases (Nigam et al., 1990).

Pre-identified male parent plant is removed by breaking the hypanthium. The calyx, standard, and wing petals are detached for ease in operation. The keel petal is gently pressed between the thumb and index finger to 
squeeze the sticky pollen mass out from the anthers. The sticky lump of pollen is deposited on the tip of the stigma of the emasculated flower. Total 15 hybrids and their 6 parents were planted in Randomized complete block design (RCBD) with three replications during Kharif 2016. Each entry was raised in single row of $3 \mathrm{~m}$ length with a row to row spacing $45 \mathrm{~cm}$ apart with $15-20 \mathrm{~cm}$ interplant distances.

Combining ability analysis was carried out by the procedure given by Griffing"s (1956a) as per the method 2 (model II) this is applied for the set of data involving parents and $F_{1} \mathrm{~S}$ excluding reciprocals.

\section{Results and Discussion}

The variance due to parents (gca) was highly significant for all the thirteen characters viz., days to $50 \%$ flowering, days to maturity, plant height at harvest $(\mathrm{cm})$, number of primary branches per plant, number of secondary branches per plant, number of kernel per plant, 100 kernel weight $(\mathrm{gm})$, pod size $(\mathrm{cm})$, pod yield per plant, harvest index (\%), seed weight per plant and shelling percentage. The variance due to hybrids (sca) was also found highly significant for all the characters (Table 3).

General combining ability effects: The term, general combining ability is used to designate the average performance of a line in hybrid combination (Griffing, 1956). Study of GCA effects in combination with per se performance of parents will be effective to predict good general combiners for each trait.

The parents Kadiri-6 and ICGV 91114 identified as a good general combiner for early maturity and Kadiri-3 for number of kernel per plant and most of the traits. Estimation of gca effects revealed that the parent ICGV 91114 and JL-501 shown negative highly significant effects in the direction of early flowering. Parent Jyoti and Girnar-3 shown significant gca effect but had positive effect in the direction of late flowering. The negative GCA effects indicated their usefulness in breeding of early flowering.

The parent JL-501 identified good general combiner for number of primary branches per plant, pod size, harvest index and shelling percentage indicating this parent can be used for further crop improvement programme and this parent can also be used for developing dwarfing genotype because this showed significant negative gca effect for plant height. The parent Kadiri-3 showed significant positive gca effects for most of the traits like: number of secondary branches per plant, number of kernel per plant, 100 kernel weight and harvest index indicating also identified as a best combiner. The parent Girnar-3 showed significant positive gca effects for number of secondary branches per plant whereas three parents ICGV 91114, Kadiri-6 and Jyoti shown significant but negative gca effects ant the parent ICGV 91114 also identified as a best combiner for seed weight per plant (Table $1)$.

Among the 15 hybrids the cross Kadiri-3 x JL501 showed highest negative significant SCA effect for days to $50 \%$ flowering and the cross ICGV 91114 x JL-501 for days to maturity means that cross combination can be used for developing early maturing lines followed by Girnar x ICGV 91114.

For the character plant height the cross Jyoti $\mathrm{x}$ Kadiri-6 identified as a negative specific combiners followed by Kadiri-6 x ICGV 91114 that cross combination can be used for developing dwarf variety and for number of primary branches per plant the cross Jyoti $\mathrm{x}$ Kadiri-6 showed highest positive significant SCA effects followed by Girnar-3 x Kadiri-6 and for number of secondary branches per plant cross Jyoti x Kadiri-3 showed highest positive significant SCA effects. 
Table.1 Estimation of general combining ability for pod yield and component characters in groundnut

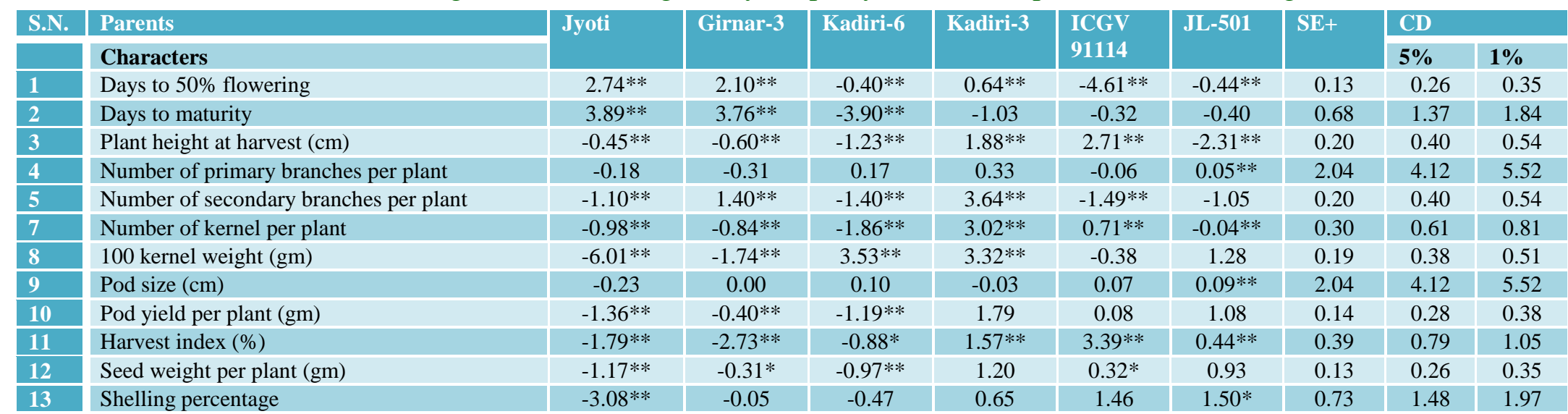

$*$, ** Significant at $0.05 \%$ and $0.01 \%$ levels, respectively

Table.2 Estimation of specific combining ability in groundnut

\begin{tabular}{|c|c|c|c|c|c|c|c|c|c|c|c|c|}
\hline Cross & $\begin{array}{l}\text { Days to } 50 \% \\
\text { flowering }\end{array}$ & $\begin{array}{c}\text { Days to } \\
\text { maturity }\end{array}$ & $\begin{array}{l}\text { Plant height at } \\
\text { harvest }(\mathrm{cm})\end{array}$ & $\begin{array}{c}\text { No. of primary } \\
\text { branches }\end{array}$ & $\begin{array}{l}\text { No. of secondary } \\
\text { branches }\end{array}$ & $\begin{array}{l}\text { No. of } \\
\text { kernel }\end{array}$ & $\begin{array}{l}100 \text { kernel } \\
\text { weight }\end{array}$ & $\begin{array}{l}\text { Pod size } \\
(\mathrm{cm})\end{array}$ & $\begin{array}{l}\text { Pod weight } \\
\text { (gm) }\end{array}$ & $\begin{array}{c}\text { Harvest index } \\
(\%)\end{array}$ & $\begin{array}{l}\text { Seed weight } \\
\text { (gm) }\end{array}$ & $\begin{array}{c}\text { Shelling } \\
\%\end{array}$ \\
\hline Jyoti x Girnar-3 & $0.39 *$ & $2.22 * *$ & $-1.41 * *$ & $-0.83 * *$ & $-2.00 * *$ & $-3.01 * *$ & $-6.28 * *$ & $-0.06^{*}$ & $-1.86^{* *}$ & 0.55 & $-1.17 * *$ & -0.11 \\
\hline Jyoti x Kadiri-6 & $0.89 * *$ & $-2.78 * *$ & $-6.40 * *$ & $0.77 * *$ & $-0.88 * *$ & 0.06 & $2.98 * *$ & $0.13 * *$ & $0.40^{*}$ & $-2.11 * *$ & 0.22 & $-2.66^{* *}$ \\
\hline Jyoti x Kadiri-3 & $3.85^{* *}$ & -0.32 & $0.56^{*}$ & $0.19^{*}$ & $5.37 * *$ & $2.89 * *$ & $-6.42 * *$ & $-0.50 * *$ & -0.31 & $9.01 * *$ & 0.34 & $6.84 * *$ \\
\hline Jyoti x ICGV 91114 & $-2.90 * *$ & $-9.03 * *$ & $2.00 * *$ & -0.01 & $1.18 * *$ & 0.43 & $2.20 * *$ & $0.36^{* *}$ & 0.17 & $-5.14 * *$ & $-0.50 * *$ & $-5.22 * *$ \\
\hline Jyoti x JL-501 & $2.26^{* *}$ & $5.05^{* *}$ & 0.17 & $0.52 * *$ & -0.42 & $-3.56^{* *}$ & $-4.85 * *$ & $0.07 * *$ & $-1.75^{* *}$ & $-2.39 * *$ & $-1.17 * *$ & $1.98^{*}$ \\
\hline Girnar-3 x Kadiri-6 & $0.85^{* *}$ & $-7.65 * *$ & $-4.54 * *$ & $0.75 * *$ & $-2.98 * *$ & $-1.98 * *$ & $0.97 * *$ & $0.20 * *$ & $0.78^{* *}$ & $-2.57 * *$ & 0.11 & $-6.35^{* *}$ \\
\hline Girnar-3 x Kadiri-3 & $-0.86^{* *}$ & $-7.20 * *$ & $5.18^{* *}$ & $0.29 * *$ & $-1.12 * *$ & $-1.54 * *$ & $-1.71 * *$ & $-0.06 *$ & $-1.39 * *$ & $-5.98 * *$ & $-1.93 * *$ & $-11.58^{* *}$ \\
\hline $\begin{array}{c}\text { Girnar-3 x ICGV } \\
91114 \\
\end{array}$ & $0.72 * *$ & $-9.24 * *$ & $-1.94 * *$ & 0.07 & 0.48 & -0.49 & $1.92 * *$ & $-0.20 * *$ & $0.80 * *$ & $1.81 * *$ & $0.51 * *$ & $1.83 *$ \\
\hline Girnar-3 x JL-501 & $-0.45 * *$ & -0.15 & $-3.48 * *$ & $-0.96^{* *}$ & $-1.30 * *$ & $-1.02 * *$ & $2.68 * *$ & 0.04 & 0.22 & 0.38 & -0.15 & $-2.00 *$ \\
\hline Kadiri-6 x Kadiri-3 & $-4.03 * *$ & 0.14 & $-0.77 * *$ & $0.18^{*}$ & $2.82 * *$ & $4.98 * *$ & $7.34 * *$ & $-0.10 * *$ & $3.09 * *$ & $10.47 * *$ & $2.17 * *$ & 0.20 \\
\hline $\begin{array}{c}\text { Kadiri-6 x ICGV } \\
91114 \\
\end{array}$ & $-1.11 * *$ & $-3.57 * *$ & $-5.24 * *$ & -0.10 & 0.07 & $5.49 * *$ & $-6.71 * *$ & $-0.27 * *$ & $-0.87 * *$ & $1.43 * *$ & $-0.41 *$ & $4.02 * *$ \\
\hline Kadiri-6 x JL-501 & $-2.61 * *$ & $-1.49 * *$ & $-2.77 * *$ & $0.42 * *$ & 0.08 & $-4.53 * *$ & $-2.03 * *$ & $-0.49 * *$ & $-1.45^{* *}$ & $-6.19 * *$ & $-1.62 * *$ & $-8.63 * *$ \\
\hline $\begin{array}{c}\text { Kadiri-3 x ICGV } \\
91114\end{array}$ & $-3.15^{* *}$ & $0.55^{*}$ & -0.30 & $0.42 * *$ & $1.44 * *$ & $-2.42 * *$ & $-2.30 * *$ & $-0.10 * *$ & -0.27 & -0.62 & $-0.92 * *$ & $-5.94 * *$ \\
\hline Kadiri-3 x JL-501 & $-5.65 * *$ & $-2.36 * *$ & $2.91 * *$ & $-1.17 * *$ & $1.48 * *$ & $4.61 * *$ & $1.36^{* *}$ & $0.08 * *$ & $2.98 * *$ & $-3.00 * *$ & $1.82 * *$ & -1.08 \\
\hline ICGV 91114 x JL-501 & $-2.40 * *$ & $-11.07 * *$ & $3.42 * *$ & $-0.60 * *$ & $-1.20 * *$ & $-1.50^{* *}$ & $0.95 * *$ & $0.07 * *$ & $0.39 *$ & $-1.23 *$ & $-0.79 * *$ & $-7.65 * *$ \\
\hline $\mathrm{SE} \pm($ sij) & 0.15 & 0.26 & 0.24 & 0.075 & 0.24 & 0.37 & 0.23 & 0.024 & 0.17 & 0.47 & 0.17 & 0.88 \\
\hline CD 5\% & 0.30 & 0.53 & 0.49 & 0.15 & 0.49 & 0.75 & 0.46 & 0.05 & 0.34 & 0.95 & 0.34 & 1.78 \\
\hline CD 1\% & 0.41 & 0.70 & 0.65 & 0.20 & 0.65 & 1.00 & 0.62 & 0.06 & 0.46 & 1.27 & 0.46 & 2.38 \\
\hline
\end{tabular}

*, ** Significant at $0.05 \%$ and $0.01 \%$ levels, respectively 
Table.3 Analysis of variance for combining ability in groundnut

\begin{tabular}{|c|c|c|c|c|}
\hline S.N. & Character & \multicolumn{3}{|c|}{ Mean sum of squares } \\
\hline & & GCA df $=5$ & SCA df $=15$ & Error $\mathrm{df}=40$ \\
\hline 1 & Days to $50 \%$ flowering & $54.14 * *$ & $12.07 * *$ & 0.075 \\
\hline 2 & Days to maturity & $81.80 * *$ & $63.54 * *$ & 0.22 \\
\hline 3 & Plant height at harvest $(\mathrm{cm})$ & $29.31 * *$ & $19.69 * *$ & 0.187 \\
\hline 4 & Number of primary branches per plant & $0.43 * *$ & $0.49 * *$ & 0.019 \\
\hline 5 & Number of secondary branches per plant & $34.75 * *$ & $6.8 * *$ & 0.19 \\
\hline 7 & Number of kernel per plant & $23.68 * *$ & $12.87 * *$ & 0.45 \\
\hline 8 & 100 kernel weight $(\mathrm{gm})$ & $102.96 * *$ & $19.38 * *$ & 0.17 \\
\hline 9 & Pod size $(\mathrm{cm})$ & $0.13 * *$ & $0.7 * *$ & 0.002 \\
\hline 10 & Pod yield per plant (gm) & $12.5^{* *}$ & $2.67 * *$ & 0.1 \\
\hline 11 & Harvest index $(\%)$ & $40.89 * *$ & $26.67 * *$ & 0.75 \\
\hline 12 & Seed weight per plant (gm) & $7.7 * *$ & $1.67 * *$ & 0.084 \\
\hline 13 & Shelling percentage & $23.22 * *$ & $48.75 * *$ & 2.6 \\
\hline
\end{tabular}

$*, * *$ Significant at 5 and 1 per cent levels, respectively.

Table.4 Components of gca and sca and their predictability ratios in groundnut

\begin{tabular}{|l|l|c|c|c|}
\hline \multicolumn{1}{|c|}{ S.N. } & \multicolumn{2}{|c|}{ Type of gene action } & Predictability ratio \\
\hline & & $\boldsymbol{\sigma}^{\mathbf{2}}$ & $\boldsymbol{\sigma}^{\mathbf{2}} \mathbf{S}$ & $\mathbf{2} \boldsymbol{\sigma}^{\mathbf{2}} \mathbf{g} \mathbf{2} \boldsymbol{\sigma}^{\mathbf{2}} \mathbf{g}+\boldsymbol{\sigma}^{\mathbf{2}} \mathbf{S}$ \\
\hline $\mathbf{1}$ & Days to 50\% flowering & 0.007 & 0.040 & 0.259 \\
\hline $\mathbf{2}$ & Days to maturity & 0.022 & 0.110 & 0.286 \\
\hline $\mathbf{3}$ & Plant height (cm) & 0.019 & 0.100 & 0.275 \\
\hline $\mathbf{4}$ & Number of primary branches per plant & 0.001 & 0.010 & 0.167 \\
\hline $\mathbf{5}$ & Number of secondary branches per plant & 0.020 & 0.100 & 0.286 \\
\hline $\mathbf{7}$ & Number of kernel per plant & 0.046 & 0.240 & 0.277 \\
\hline $\mathbf{8}$ & 100 kernel weight (gm) & 0.017 & 0.089 & 0.276 \\
\hline $\mathbf{9}$ & Pod size (cm) & 0.000 & 0.001 & 0.286 \\
\hline $\mathbf{1 0}$ & Pod yield per plant (gm) & 0.010 & 0.053 & 0.274 \\
\hline $\mathbf{1 1}$ & Harvest index (\%) & 0.078 & 0.402 & 0.280 \\
\hline $\mathbf{1 2}$ & Seed weight per plant (gm) & 0.008 & 0.045 & 0.262 \\
\hline $\mathbf{1 3}$ & Shelling (\%) & 0.271 & 1.390 & 0.281 \\
\hline
\end{tabular}

The highest positive significant SCA effects have shown by cross Kadiri-6 x ICGV 91114 followed by Kadiri-6 x Kadiri-3 for number of kernel per plant and Kadiri-6 x Kadiri-3 again showed highest SCA effects for 100 kernel weight and Jyoti x ICGV 91114 for pod size, Kadiri-3 x JL-501 for pod yield, Kadiri-6 x Kadiri-3 for harvest index and seed weight per plant (Table 2).
At the present investigation pod yield per plant and all the contributing characters were found under less than unity of GCA: SCA which might be influenced by non-additive gene action and may be impressive in favor of hybrid vigour exploitation. The parents Kadiri-6 and ICGV 91114 identified as a good general combiner for early maturity and Kadiri-3 for number of kernel per plant and 
most of the traits. The crosses Kadiri-3 x JL501 and ICGV $91114 \times$ JL-501 proved to the best combination for early maturity that can be used for further breeding programmes (Table 4).

The parents Kadiri-6 and ICGV 91114 identified as a good general combiners for early maturity and Kadiri-3 for number of kernel per plant and most of the traits. The crosses Kadiri-3 x JL-501 and ICGV 91114 x JL-501 proved to the best combination for early maturity. Combining ability analysis revealed predominance of additive gene action in the expression of days to $50 \%$ flowering, plant height, number of primary branches per plant, number of secondary branches per plant, number of kernel per plant, pod size, pod yield per plant and seed weight per plant. Dominance gene action was noticed in the expression of 100 kernel weight and harvest index. In order to avoid loss of superior lines in advance segregating generations of the superior crosses one has to go isolation of these lines in $F_{2}$ by visual selection. Similar results also reported by Phudenpa et al., (2006), Dwivedi et al.,(1989), Ouedraogo et al., (1994) and Vishnuwardhan et al., (2013) and most of the others.

Combining ability analysis revealed predominance of additive gene action in the expression of days to $50 \%$ flowering, plant height, number of primary branches per plant, number of secondary branches per plant, number of kernel per plant, pod size, pod yield per plant and seed weight per plant. The results were confirmation with those of earlier workers. Vekariya et al., (2011) revealing additive gene action for number of mature pods per plants, kernel yield per plant and pod yield per plant. Dominance gene action was noticed in the expression of 100 kernel weight and harvest index. The result of non-additive gene action was also reported by Patil et al.,
(2015) for days to $50 \%$ flowering, plant height, 100-pods weight, 100-kernels weight, shelling per cent and harvest index.

The general predictability ratio which is calculated on the basis of equivalent components of genetic variances $(\mathrm{r}-2 \mathrm{~g}$ and $\mathrm{a}-$ $3 \mathrm{~s}$ ) indicated the predominance of additive genetic components for $50 \%$ flowering, plant height, number of primary branches per plant, number of secondary branches per plant and other traits. The findings of predominance of additive gene action was also reported by Patil et al., (2015) for days to 50\% flowering, plant height and 100-kernels weight, Vekariya et al., (2011) for number of mature pods per plants, kernel yield per plant and pod yield per plant and Mekonnen et al., (2014) for days to flowering and plant height. The nonadditive gene action was noticed for 100 kernel weight and harvest index. The findings of predominance of non-additive gene action was also reported by Patil et al., (2015) for days to $50 \%$ flowering, plant height, 100-pods weight, 100-kernels weight, shelling per cent and harvest index.

\section{References}

Anonymous, 2004. Food and Agricultural Organisation.

Bunting, A.H., Gibbons, R.W. and Wynne, J. C. 1985. Groundnut (Arachis hypogaea L.) pp: 747-800.

Dwivedi, K. S. L., Thendapani, and Nigam, S. N. 1989. Heterosis and Combining Ability Studies and Relationship among Fruit and Seed Characters in Peanut. Peanut Science.16:14-20.

Griffing B. 1956a. Concept of general and specific combining ability in relation to diallel crossing system. Australian Journal of Biological Science. 9: 463493.

Kempthorne, O. 1957. An introduction to Genetic Statistics. John Wiley and Sons 
Inc., New York.

Mekonnen, T.W., Wakjira, A. and Genet, T. (2014). Correlation and path coefficient analysis among yield component traits of Ethiopian mustard (Brassica carinata a. Brun) at Adet, Northwestern, Ethiopian Journal of Plant Science. 2(2): 89-96.

Nigam, S.N., Vasudeva Rao, M. J., and Gibbons, R. W. 1990. Artificial Hybridization in Groundnut. Information Bulletin no. 29. Patancheru, A.P. 502 324, India: International Crops Research Institute for the Semi-Arid Tropics.

Nwokoto, E. 1996. Peanut (Arachis hypogaea L.). In: Food and Fee from Legumes and Oilseeds. E. Nwokoto and J. Smartt, Eds. Pp. 49-63.

Ouederaogo, M., Smith, O. D., Simpson, C. E. and Besler, B. 2005.Combining ability for components of resistance to early leaf spot and yield of inter and intraspecific peanut lines. OCL. 2(2): 149-156.

Pande, S., Bandyopadhyay, R., Blümmel, M., Rao, N. J., Thomas, D., and Navi, S. S. 2003. Disease management factors influencing yield and quality of sorghum and groundnut crop residues. Field Crops Research. 84(1-2): 89-103.

Patil, S., Shivanna, S., Irappa, B. M. and Shweta. 2015. Genetic variability and character association studies for yield and yield attributing components in groundnut (Arachis hypogaea L.). International Journal of Recent Scientific Research Research. 6(6): 4568-4570.
Phudenpa, A., Jogloy, S., Toomsan, B., Wongkaew, S., Kesmala, T. and Patanothai, A.2006. Combining ability analysis for traits related to N2-fixation and agronomic traits in peanut (Arachis hypogaea L.). Songklanakarin Journal of Science and Technology. 28(3): 449457.

Upadhyaya, H. D., Reddy, L. J., Gowda, C. L. L., and Singh, S. 2006. Identification of diverse groundnut germplasm: Sources of early maturity in a core collection. Field Crops Research. 97(2-3): 261271.

Vekariya, H. B., Khanpara M. D., Vachhani, J. H., Kachhadia, V. H. Madariya, R. B. and Jivani, L. L. 2011. Variability and heritability studies in bunch groundnut (Arachis hypogaea L.). International Journal of Agricultural Sciences.7:3234.

Vishnuvardhan, K. M., Vasanthi, R.P., Reddy, K. H. P. and Reddy, B. V. B. 2014. Diallel Analysis for Yield, Yield Traits and Foliar Disease Resistance Traits in Groundnut (Arachis hypogaea L.). Indian Journal of Agriculture Research.48 (2): 113-119.

Weiss, E. A. 2000. Oilseed Crops. London: Blackwell Science.

Worthington, R. E., and Hammons, R. O. 1971. Genotypic variation in fatty acid composition and stability of Arachis hypogaea L. Oil. Oleagineaux. 26:695700.

Young, M. C. 2006. The peanut Alergy Answer Book, Fair Winds publishing, ISBN 1592332331.

\section{How to cite this article:}

Ishu Kumar Khute, S.S. Rao, Preeti Painkra and Naveen Markam. 2018. Combining Ability for Yield and Yield Components in Groundnut (Arachis hypogaea L.). Int.J.Curr.Microbiol.App.Sci. 7(02): 2798-2804. doi: https://doi.org/10.20546/ijcmas.2018.702.340 